\title{
衛星観測高精度DEMによるインドネシア国バワカラエン山の 大規模崩壊後の土砂流出の経年変化把握 \\ Temporal change in the sediment discharge from the gigantic landslide occurred on Mt. Bawakaraeng, Indonesia
}

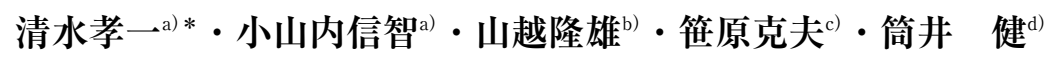 \\ Yoshikazu SHIMIZU, Nobutomo OSANAI, Takao YAMAKOSHI, Katsuo SASAHARA and Ken TSUTSUI
}

\begin{abstract}
On March 26, 2004, the gigantic landslide occurred on the caldera wall of Mt Bawakaraeng, Indonesia. This paper quantitatively shows the temporal change in the sediment discharge from the huge amount of the deposit of the landslide through the differentiation of the multi-temporal DEMs obtained by the stereo matching of two optical satellite images. Firstly, the landslide buried the original river channel completely. In the next year, gully erosion dominated on the entire landslide deposit and some part of the gully bed was found to degrade up to $60 \mathrm{~m}$. The total amount of sediment which had discharged from the area of interest was estimated to be 36.3 million $\mathrm{m}^{3}$. In the second post-event year, such a severe and entire degradation was almost terminated and some part showed a tendency of the river bed aggradations. The total amount of the discharged sediment drastically decreased and was estimated to be 8.3 million $\mathrm{m}^{3}$.
\end{abstract}

Key words : Mt. Bawakaraeng, gigantic landslide, topographic change, gully erosion, satellite remote sensing, digital elevation model

\section{和文要旨}

2004年 3 月 26 日，インドネシア国のバワカラエン山において大規模な崩壊が発生した。本論文は，バワカラエン山の大規模崩壊 による堆積土砂の崩壊発生から 2 年間の経年変化を衛星観測高精度DEMを用いて定量的に明らかにしたものである。崩壊の発生に より，旧河道を崩壊土砂が埋塞し，その後 1 年目には全般的にガリー侵食が卓越し，侵食によって年間最大で $60 \mathrm{~m}$ 程度の河床低下を もたらした部分が見られた。2 年目には一部に侵食の卓越する部分が残ったものの全般的には侵食を示す範囲がせばまり，一部に おいては堆積を示した。変化量の経年変化は崩壊発生 1 年目の流出量 36.3 百万 $\mathrm{m}^{3}$ から 2 年目には 8.3 百万 $\mathrm{m}^{3} に$ 減少した。

キーワード：バワカラエン山, 大規模崩壊, 地形変化, ガリー侵食, 衛星リモートセンシング, DEM

\section{1.はじめに}

2004年 3 月 26 日，インドネシア国スラウェシ島南部の 火山であるバワカラエン山（標高 $2,830 \mathrm{~m}$, a.s.l.) にお いてカルデラ壁の大規模な崩壊が発生した。この山体崩


規模な不安定土砂の生産後には崩壊堆積土砂の流出の増 加により下流への土砂流出が頻発することが知られてい る。

このような大規模土砂生産後の土砂流出に関する研究の 一例として，1980年に発生したアメリカ国のセントヘレ ンズ山の山体崩壊を伴う噴火後の土砂流出に関する研究 事例2)，フィリピン国における，ピナツボ山の火山噴火 後の土砂流出に関する研究事例 ${ }^{3}$ ，インドネシア国にお けるメラピ火山の1998年に発生した火砕流の堆積物の侵 食状況に関する研究事例4，そして日本国内では，雲仙 普賢岳において1991〜1995年にかけて発生した火砕流の

* 連絡著者/corresponding author

国土交通省国土技術政策総合研究所
National Institute for Land and Infrastructure Management, Ministry of Land, Infrastructure and Transport

T305-0804 茨城県つくば市旭 1

1 Asahi, Tsukuba City, Ibaraki Prefecture 305-0804, Japan

b) 独土木研究所土砂管理研究グループ

Pubric Work Research Institute, Erosion and Sediment Control Research Group 高知大学農学部

Kochi University, Faculty of Agriculture

d) 株NTTデータ

NTT DATA Corporation
堆積斜面の侵食状況に関する研究事例 5 がある。

セントヘレンズ山の研究事例 2 においては, 噴火後 20 年間の浮遊砂観測により山体崩壊地と火山灰堆積地から の流出土砂量の変化が明らかにされている。その研究事 例では，火山灰堆積地からの浮遊砂量は約 5 年で噴火前 の状態に戻ったが，山体崩壊の崩積土の堆積地からは20 年が経過してもな抒火前のレベルを大きく上回る浮遊 砂が流出していることが明らかになっている。


が噴火後から指数関数的に減少することが経年変化の調 查結果から判明している。

また, メラピ山文と雲仙普賢岳5)における研究では, 火 砕流堆積斜面の測量結果，前者では地上測量, 後者では 空中写真測量）に基づいて, 土砂生産量の経年変化が検 討されるとともに, 火砕流堆積斜面におけるガリーの発 達特性が明らかにされた。

以上の研究より大規模土砂生産後の下流への土砂流出 の特性が明らかになってきた。火山活動に伴う火砕流堆 積物からの土砂流出に関する研究事例はある程度蓄積さ れており, 流出土砂量は数年間で急激に減少することが 判明してきた。しかし大規模山体崩壊後の土砂流出につ いては，セントヘレンズの研究事例程度しかなく，未だ その実態は十分に分かっているとはいえない。これにつ 
いては研究事例の蓄積が必要である。

本研究は山体崩壊の発生前後の衛星観測高精度DEM (Digital Elevation Model：数值標高モデル) を用いて, 山体崩壊により発生した不安定土砂堆積地の地形変化の 定量的評価を行い，大規模崩壊跡地からの土砂流出量の 経年変化過程を明らかにするものである。

\section{2. バワカラエン山体崩壊の概要}

\section{1 バワカラエン山の概要}

バワカラエン山（標高 $2,830 \mathrm{~m} ）$ は，インドネシア共 和国スラウェシ島南西部（図－1）に位置し，スラウェ シ島南部の主要都市であるマカッサルで海に注ぐジェネ ベラン川の源流域に位置する。

図 -2 に本研究対象範囲を含む地質図を示す。バワカ ラエン山を構成する地質はLompobattang volcanicsに属 す。Lompobattang volcanicsは更新世に火山活動によっ て形成された安山岩質の火山岩類で, 溶岩, 火砕岩, お よび二次鉱床から形成されている。


Fig. 1 Location of Mt. Bawakaraeng
図 - 3 に本研究対象域の傾斜角分布図を示す。明瞭な カルデラ壁が形成されており，カルデラ内は過去のカル デラ壁の崩壊によると思われる堆積物からなる比較的傾 斜の緩やかな面が構成されている。この平坦面のほぼ中 央を東西方向にジェネベラン川が流下している。

図－4にバワカラエン山麓にあるレンケセ集落（写真 - 1 B付近の左岸側）で計測されている降雨量につい て示す9)。2005年12月から2006年11月までの年間降雨量 は $3,531 \mathrm{~mm}$ ，日最大雨量は $238 \mathrm{~mm} （ 2005$ 年 1 月 25 日）を 記録している。

\subsection{3. 26に発生した山体崩壊について}

山体崩壊により，死者・行方不明者 32 名，住居 12 棟を 含む1, 500haの農地等が埋没する直接被害が生じた。崩 壊した山稜の標高は約 $2,500 \mathrm{~m}$ から $2,600 \mathrm{~m} て ゙ ，$ 平均崩壊 比高は $750 \mathrm{~m}$ ，平均崩壊幅が $1,600 \mathrm{~m}$ 。推定崩壊土砂量は 地山土砂量で約 2 億 $\mathrm{m}^{3}$ とされている

山体崩壊の発生したジェネベラン川の中流域には, ジェネベラン川の洪水調節，下流都市の灌溉，電力供給

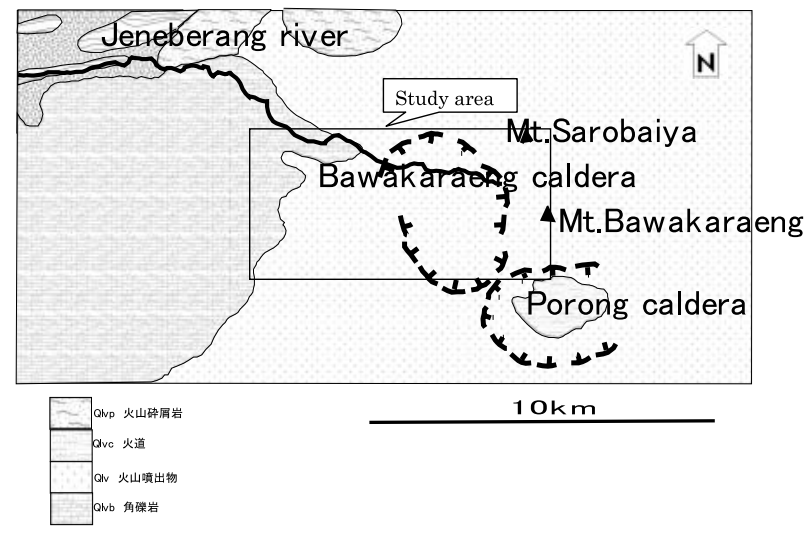

図ー 2 バワカラエン山周辺の地質図

Fig. 2 Geologic map in the vicinity of Mt. Bawakaraeng

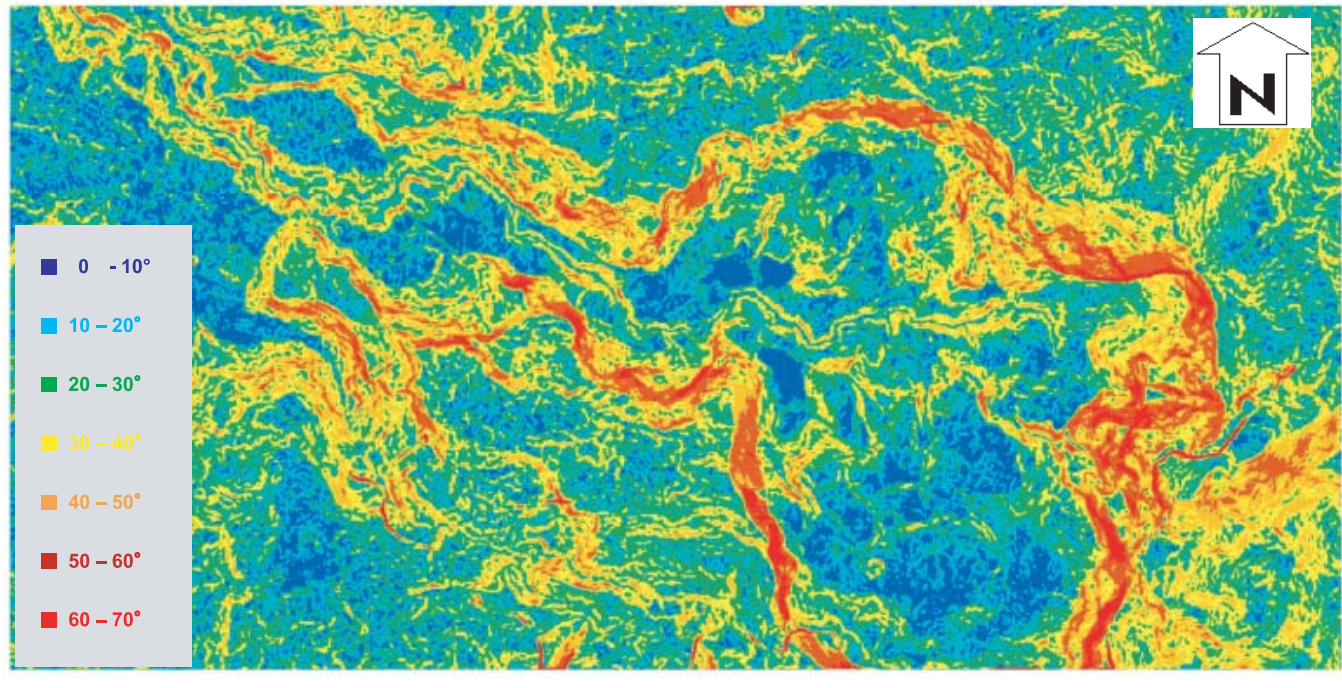

$10 \mathrm{~km}$

図一 3 傾斜角分布図 (2005)

Fig. 3 Distribution map of slope angle of the ground created from the DEM obtained in 2005 
日雨量グラフ

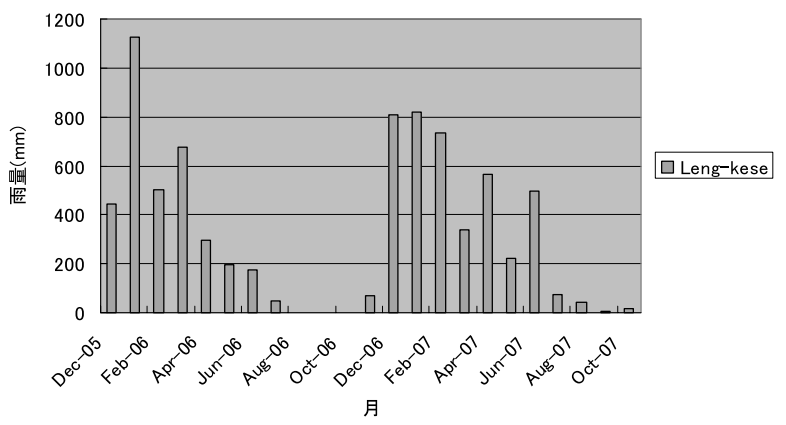

図一 4 月雨量グラフ (2005.12 )

Fig. 4 Monthly rainfall from December 2005 to October 2007.
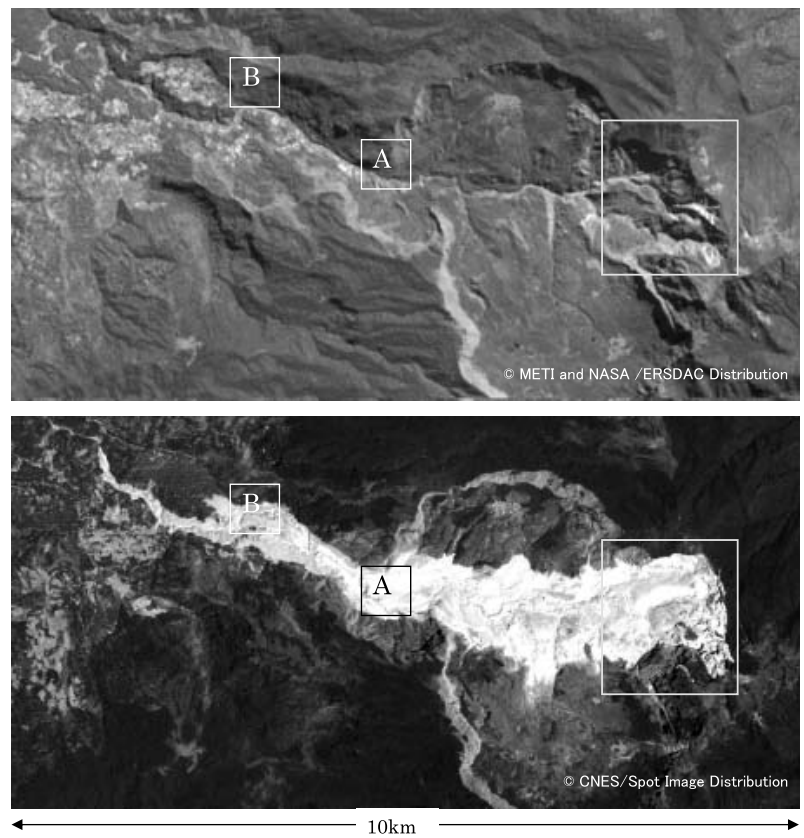

写真ー 1 解析に用いたバワカラエン山周辺の衛星画像 (上：2001年 7 月 7 日 (発生前), 下：2004年11月 2 日 (発生後))

Photo. 1 An example of satellite images of Mt. Bawakaraeng and its vicinity

(Upper: July 7, 2001 before the landslide, Lower: Nov. 2, 2004 after the landslide)

を目的としたビリビリダム（総貯水量約 3.8 億 $\mathrm{m}^{3}, 1999$ 年完成）が建設されている。崩壊土砂のダム貯水池への 堆積による貯水容量の減少 (埋没), 水道・灌溉用水の 污濁など，二次被害が問題となっているところである。

\section{3．使用する衛星観測高精度DEMについて}

\section{1 衛星データについて}

表ー 1 に示す衛星画像よりDEMを作成した。

崩壞発生前のDEMはTerra衛星搭載のASTERセンサ （以下，ASTERと記載）による画像から作成した（以下， ASTER-DEMと記載)。ASTER画像の地表分解能は15 $\mathrm{m}$ で撮影幅は60kmである。この画像から作成したDEM
表一 1 解析に用いた衛星画像

Table 1 Satellite images utilized in this study

\begin{tabular}{|c|c|c|c|}
\hline 撮影日時 & 事項 & 衛星画像 & $\mathrm{BH}$ 比 \\
\hline 2001 年 7 月 7 日 & 崩壊前 & ASTER & 0.60 \\
\hline 2004 年 10 月 13 日 & \multirow{2}{*}{ 崩壊発生年 } & \multirow{2}{*}{ SPOT-5 } & \multirow{2}{*}{0.58} \\
\hline 2004 年 11 月 2 日 & & & \\
\hline 2005 年 9 月 20 日 & \multirow{2}{*}{ 崩壊後 1 年 } & \multirow{2}{*}{ SPOT-5 } & \multirow{2}{*}{0.61} \\
\hline 2005 年 9 月 26 日 & & & \\
\hline 2006 年 8 月 4 日 & \multirow{2}{*}{ 崩壊後 2 年 } & \multirow{2}{*}{ SPOT -5} & \multirow{2}{*}{0.56} \\
\hline 2006 年 8 月 29 日 & & & \\
\hline
\end{tabular}

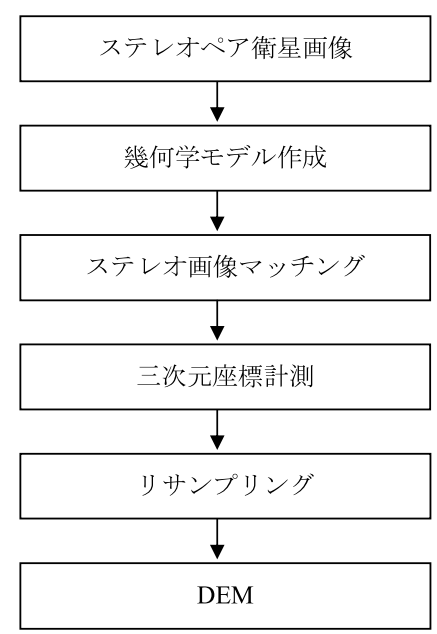

図－5 衛星画像からDEM作成のフロー

Fig. 5 Flow chart of the DEM generation processes from stereoscopic satellite imagery

の地表分解能は $15 \mathrm{~m}$ であり，その標高精度は約 $10 ３ 0 \mathrm{~m}$ $(1 \sigma)$ である7”。なお，ASTERは直下視と後方視の 2 つのセンサを搭載していることから，1回の撮影でステ レオペア画像を取得可能である。ステレオペア画像の三 次元座標計測性能を表すBH比（Base to Height Ratio： 基線／高度比）は0.60である。

崩壊発生後のDEMはSPOT- 5 衛星搭載のHRGセンサ (以下, SPOT- 5 と記載) による画像から作成したもの (以下, SPOT-DEMと記載) である。SPOT- 5 画像の分 解能は $2.5 \mathrm{~m}$ で撮影幅は $60 \mathrm{~km}$ である。この画像から作成 したDEMの地表分解能は $5 \mathrm{~m}$ であり，その標高精度は 約 $5 \mathrm{~m}(1 \sigma)$ である ${ }^{8)}$ 。なお, SPOT- 5 は, 東西方向に 撮影角度を変更して画像取得が可能であることから, 異 方向からの 2 回の画像撮影行い，ステレオペア画像を取 得した。ステレオペア画像のBH比は2004年画像が $0.58 ， 2005$ 年画像が $0.61 ， 2006$ 年画像が 0.56 である。

\subsection{DEMの抽出方法}

図ー5にDEMの抽出方法を示す。まず，衛星位置・ 姿勢情報，センサモデルを利用して画像の各画素の視線 方向を表した幾何学モデルを作成する。次に, 相互相関 に基づくステレオ画像マッチングによりステレオ画像間 



\section{図一 6 SPOT-DEMの精度評価結果}

Fig. 6 The result of accuracy evaluation of the SPOTDEM
の画素位置を対応付ける。続いて，幾何学モデルと画素 位置の対応付け結果を用いて，視線方向の交点を算出す ることにより地表の三次元座標を計測する。そして，計 測結果をメッシュ単位に再構成してDEMを作成する。

山体崩壊発生後の地形変化を追跡するためのSPOTDEMについて，その性能を検証するため，(1)差分処理 の精度 (相対標高誤差) および(2)平面位置精度（相対平 面誤差）の検証を行った。(1)差分処理の精度について は，2004年と2005年のSPOT-DEMを用いて，地形変化 が発生しなかったと考えられる領域において，差分誤差 を検証した。差分誤差のヒストグラムを図ー 6 に示す。 差分処理の精度は約 $3 \mathrm{~m}(1 \sigma)$ であった。(2)平面位置 精度については，DEMに基づく 2 時期の $2.5 \mathrm{~m}$ 解像度才 ルソ画像を用いて，画像上で位置を特定できる 5 点の参 照点を選定して, 平面位置を比較した（図－6参照）。 その結果，2004年と 2005 年データ間，2005年と2006年 デー夕間で共に，8近傍の 1 画素 $(3.5 \mathrm{~m})$ 以内に収まっ ていた。本研究で使用したSPOT-DEMの空間分解能は $5 \mathrm{~m}$ であるため，平面位置精度はその分解能以内である。 なお，画像マッチングの䛊差領域では，上記の平面誤差 は大きくなることが想定されるが，(1)差分処理の精度評 価の結果から，大部分の領域では本数值が適用可能であ ると考えられる。

4. 衛星観測高精度DEMによる地形変動状況について

4.1 山体崩壊の発生について

図 -7 に崩壊発生前の 2001 年のDEM と崩壊発生後の 2004年のDEMにより算出された標高の差を計算した結

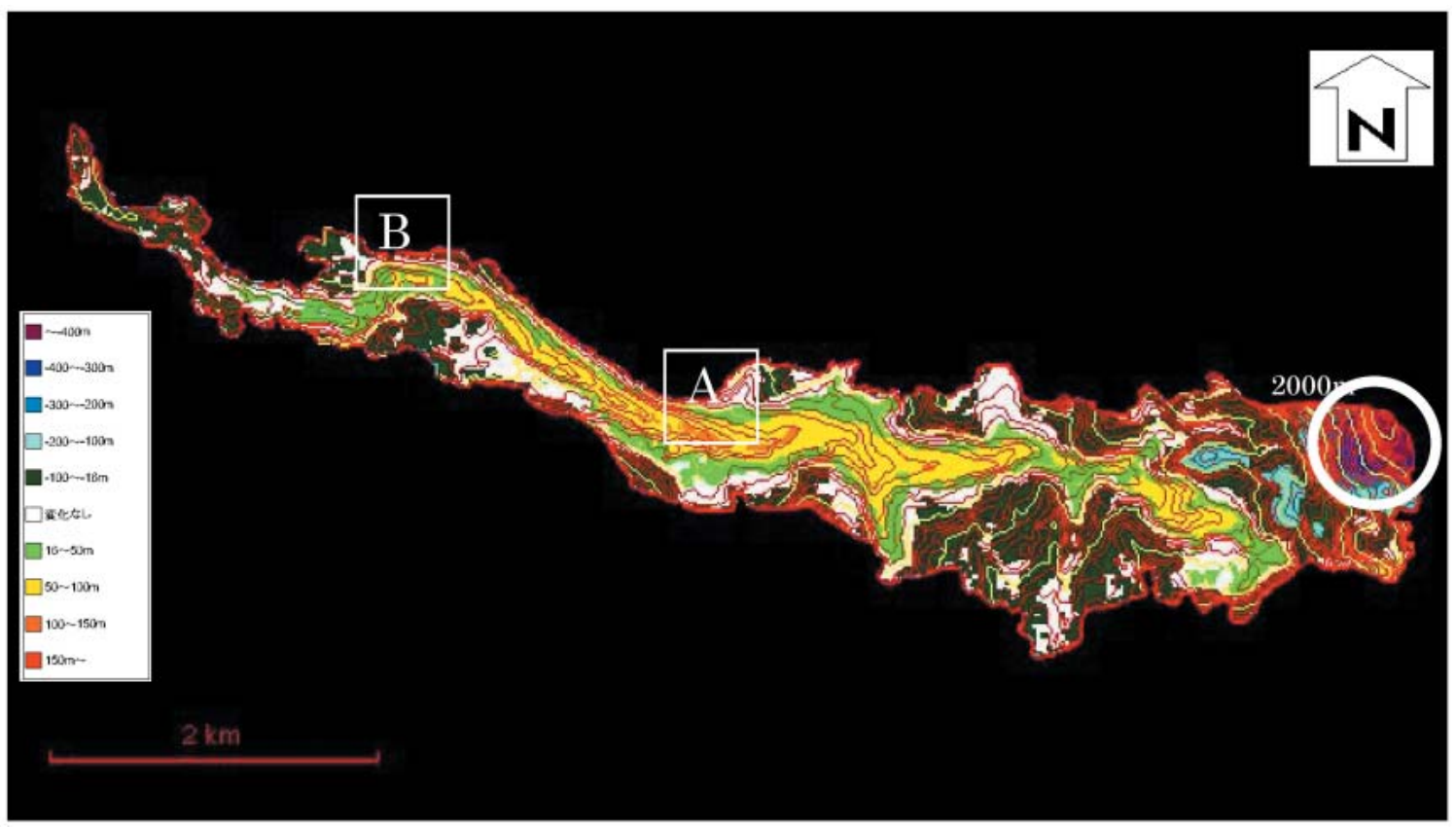

図－7 DEMの差分処理結果 $(2001-04)$

※一方向の変化 : $187,555,000 \mathrm{~m}^{3} \quad$ 十方向の変化 $108,949,000 \mathrm{~m}^{3}$

Fig. 7 The result of the differentiation of the multi-temporal DEMs in 2004 and 2001.

Total degradations : $187,555,000 \mathrm{~m}^{3}$, Total aggradations : $108,949,000 \mathrm{~m}^{3}$ 
果について示す。ここで，DEMの標高誤差は2001年の ASTER-DEMについて大まかに $15 \mathrm{~m}$ 程度であり，2004年 のSPOT-DEMについて大まかに $5 \mathrm{~m}$ 程度であるため，2 つのDEMの差分を求める際に誤差伝搬の法則により 16 $\mathrm{m}$ の誤差を考慮して， $\pm 16 \mathrm{~m}$ は変化がないものとして考 える。

図－7には2001年のDEMより生成した $20 \mathrm{~m}$ 等高線を




赤色で示した。なお，差分処理は2004年の衛星画像（写 真－1）で明白色を示す崩壊地および崩壊土砂の堆積地 のみを処理した。

図 - 7 を見るとカルデラの北西側に著しい低下域（円 で示した範囲）があることがわかる。DEMの差分処理 によると最大で約 $470 \mathrm{~m}$ の低下を示している。写真 -2 にカルデラ壁の崩壊状況について示す。写真中の2002年 の稜線が崩壊発生後の2004年に低下していることがわか る。この稜線を含む崩壊により図 - 7 の北西の低下域(円
で示した範囲）が生じたことがわかる。

カルデラ壁の崩壊により発生した崩壊土砂は，旧ジェ ネベラン川河道に沿って堆積しジェネベラン川が下刻し ていた谷を最大で約 $140 \mathrm{~m}$ 上昇させていることが判読で きる。写真 -3 に崩壊発生直後のカルデラ出口付近（写 真 - 1 のA付近）の状況を示す。崩壊土砂の堆積により 谷地形がほぼ平坦な面となっている状況が確認される。 これは，図-7で表現されている谷地形を埋めた上昇域 と調和的な結果を示している。

崩壊発生前（2001）のDEMと崩壊発生後（2004）の DEMの差分処理で計算された，崩壊により標高が低下 した範囲の体積（山体崩壊体積にほほ等しい）は約 185.8 百万 $\mathrm{m}^{3}$ でその面積は約 1.8 千万 $\mathrm{m}^{2}$ あり，標高が上昇した 範囲の体積（山体崩壊土砂の堆積した量）は約108.3百 万 $\mathrm{m}^{3}$ でその面積は約 4.3 千万 $\mathrm{m}^{2}($ 表 -2$)$ ，その差の約 77.5 百万 $\mathrm{m}^{3}$ は下流に流下したものと考えられる。 土砂量の算出にあたっては，誤差を見込んで変化なしの 範囲 $\pm 16 \mathrm{~m}$ 除外して算出している。
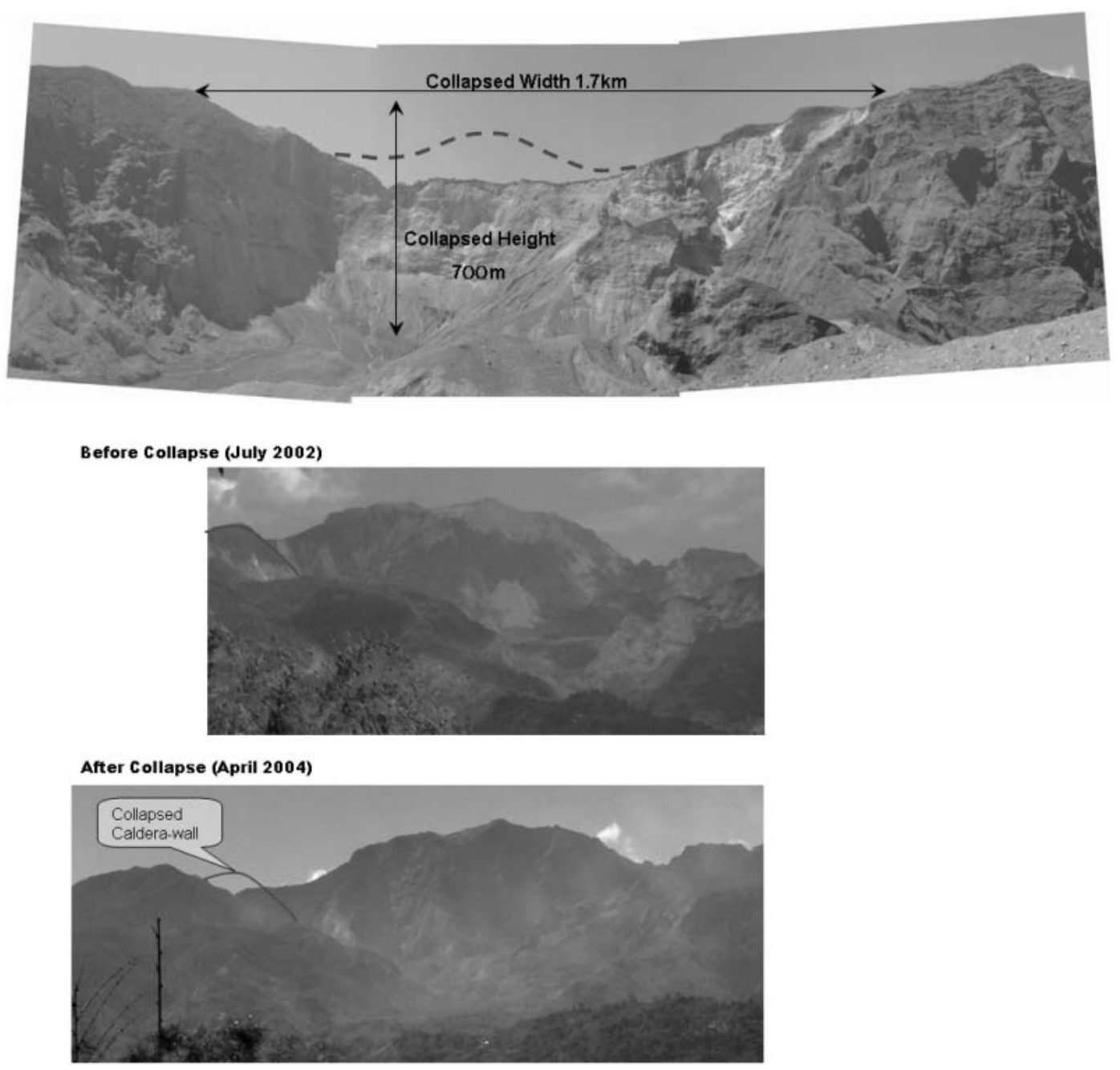

写真一 2 カルデラ壁崩壊源の状況(6)より引用)

上段・下段：崩壊後のカルデラ全景；中段：崩壊前のカルデラ全景

Photo 2 Photographs of Mt. Bawakaraeng caldera before and after the landslide ${ }^{6)}$

Upper \& Lower: Photos of the caldera after the landslide, Middle : Photo before the landslide 


\section{Pushed out Debris}
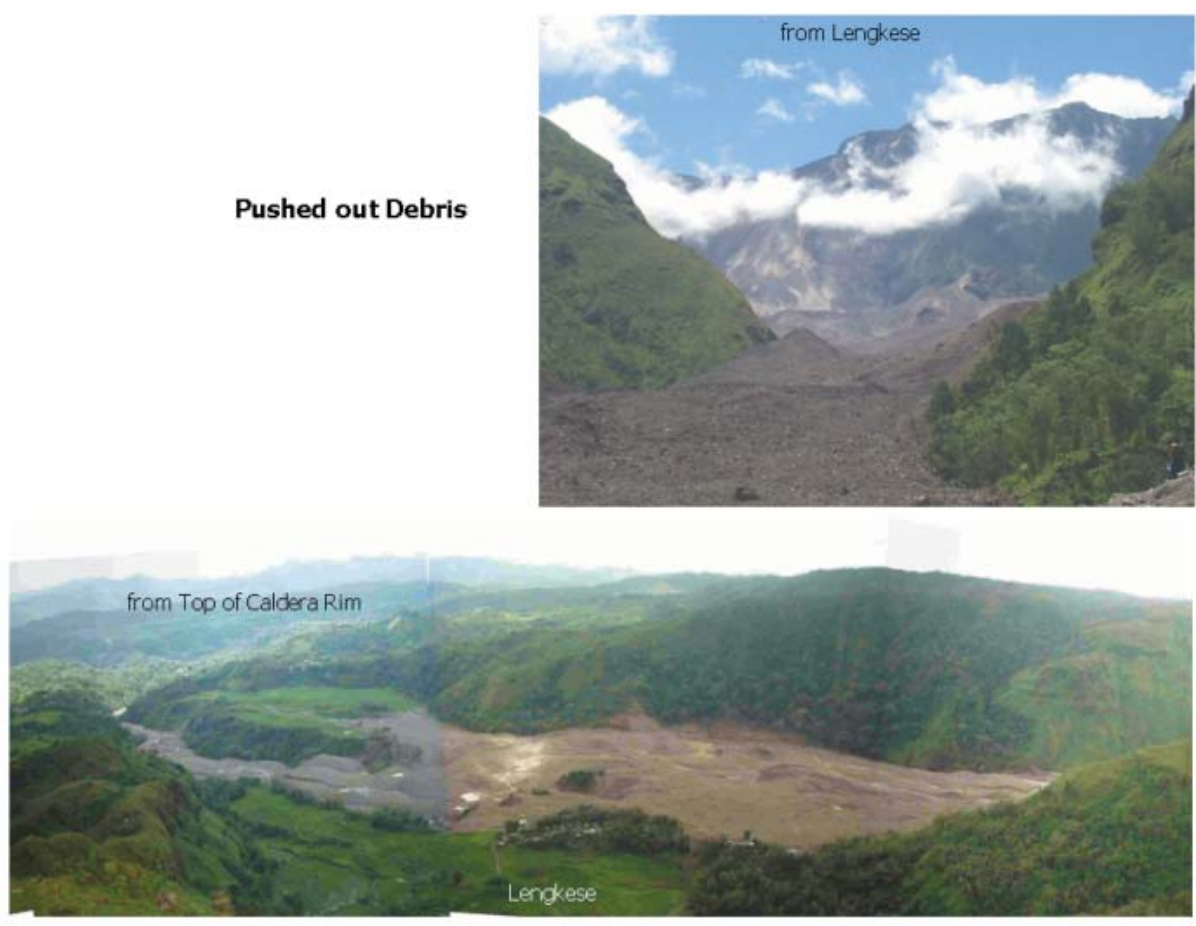

写真一 3 崩壊土砂の堆積状況(6)より引用)

Photo 3 Photographs of the landslide deposit ${ }^{6}$

Upper : Frontal view taken from Lengkese village Lower: Oblique view taken from the top of the caldera rim.

\section{表－ 2 DEM差分処理による変化量}

Table 2 The temporal change in the total aggradations, the total degradations and the residuals obtained from the differentiations of the multi-temporal DEMs

\begin{tabular}{|c|c|c|c|c|c|c|c|}
\hline & \multicolumn{3}{|c|}{ 一方向 } & \multicolumn{3}{|c|}{ +方向 } & \multirow[b]{2}{*}{ 差 } \\
\hline & 面積 (m2) & 体積 (m3) & 平均深さ $(\mathrm{m})$ & 面積 (m2) & 体積 (m3) & 平均深さ $(\mathrm{m})$ & \\
\hline 崩壊 & $18,336,620$ & $-187,555,000$ & -10.23 & $42,810,500$ & $108,949,000$ & 2.54 & 000 \\
\hline 崩壊発生後 1 年 & $2,171,730$ & $-37,480,000$ & -17.26 & 166,050 & $1,217,000$ & 7.33 & $-36,263,000$ \\
\hline 崩壊発生後2年 & 946,225 & $-11,360,000$ & -12.01 & 334,175 & $3,023,000$ & 9.05 & $-8,337,000$ \\
\hline
\end{tabular}

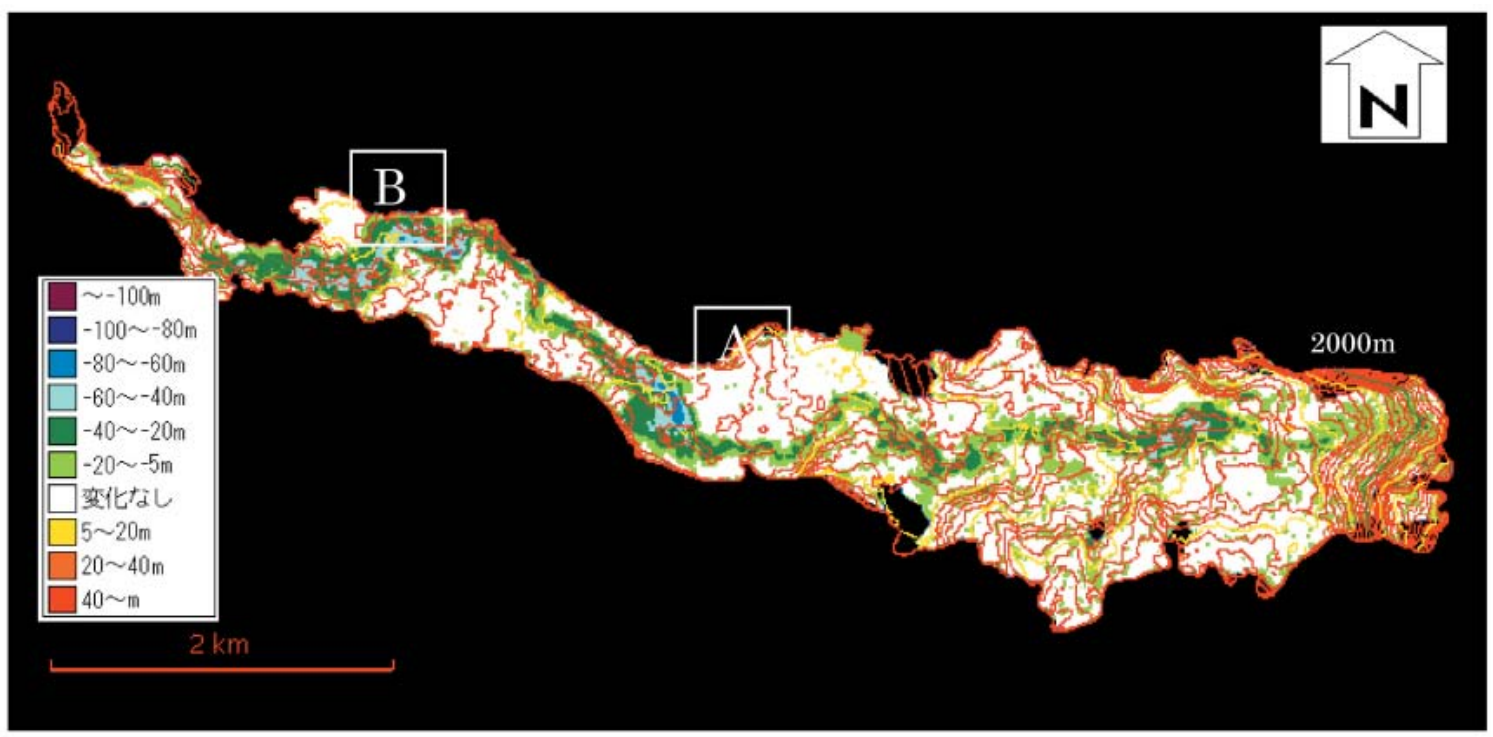

図－8ＤEMの差分処理結果 (2004-05)

※一方向の変化 : $37,480,000 \mathrm{~m}^{3} \quad$ 十方向の変化 $1,217,000 \mathrm{~m}^{3}$

Fig. 8 The result of the differentiation of the multi-temporal DEMs in 2005 and 2004.

Total degradations : $37,480,000 \mathrm{~m}^{3}$, Total aggradations : $1,217,000 \mathrm{~m}^{3}$ 


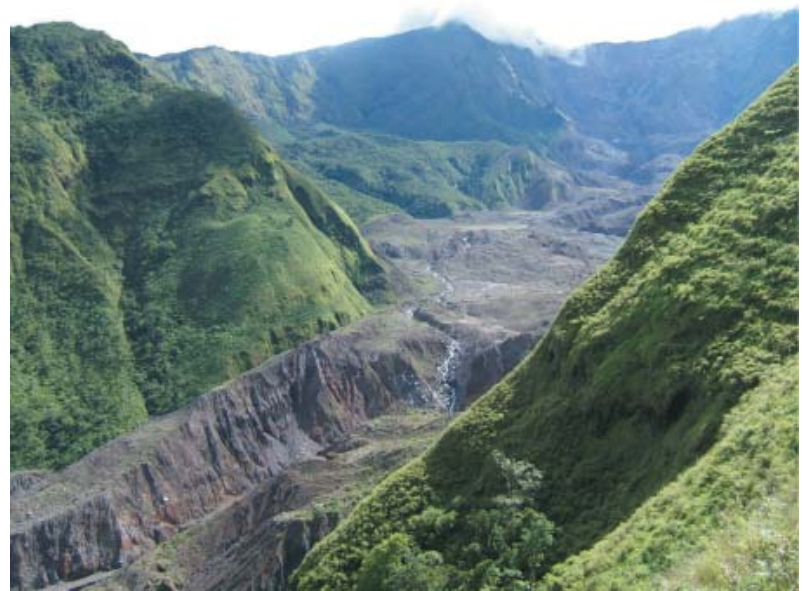

写真ー 4 カルデラ出口付近(A)の状況（2005）

Photo 4 Oblique view of the exit of the caldera of Mt. Bawakaraeng

This photo was taken in 2005.

\section{2 山体崩壊の発生 1 年後について}

図 -8 に崩壊発生年の 2004 年とその 1 年後の 2005 年の DEMにより算出された標高の差を計算した結果を示す。 大まかに $5 \mathrm{~m}$ の標高誤差がある 2 時期のSPOT-DEMの 差分処理なので誤差伝搬の法則により \pm 5 mは変化がな いものと考える。

図ー8には2004年のDEMより生成した $20 \mathrm{~m}$ 等高線を図 - 7 同様に重ね合わせた。

変化のある領域では全般的に低下傾向が卓越している が，堆積後の降雨によるガリー侵食によると思われる連 続した低下域の帯がみられる一方，図-8 AやB付近(写 真－1のA，Bと同じ）ではガリーの側方侵食による幅 広い低下域も確認された。この低下域での変化量は最大
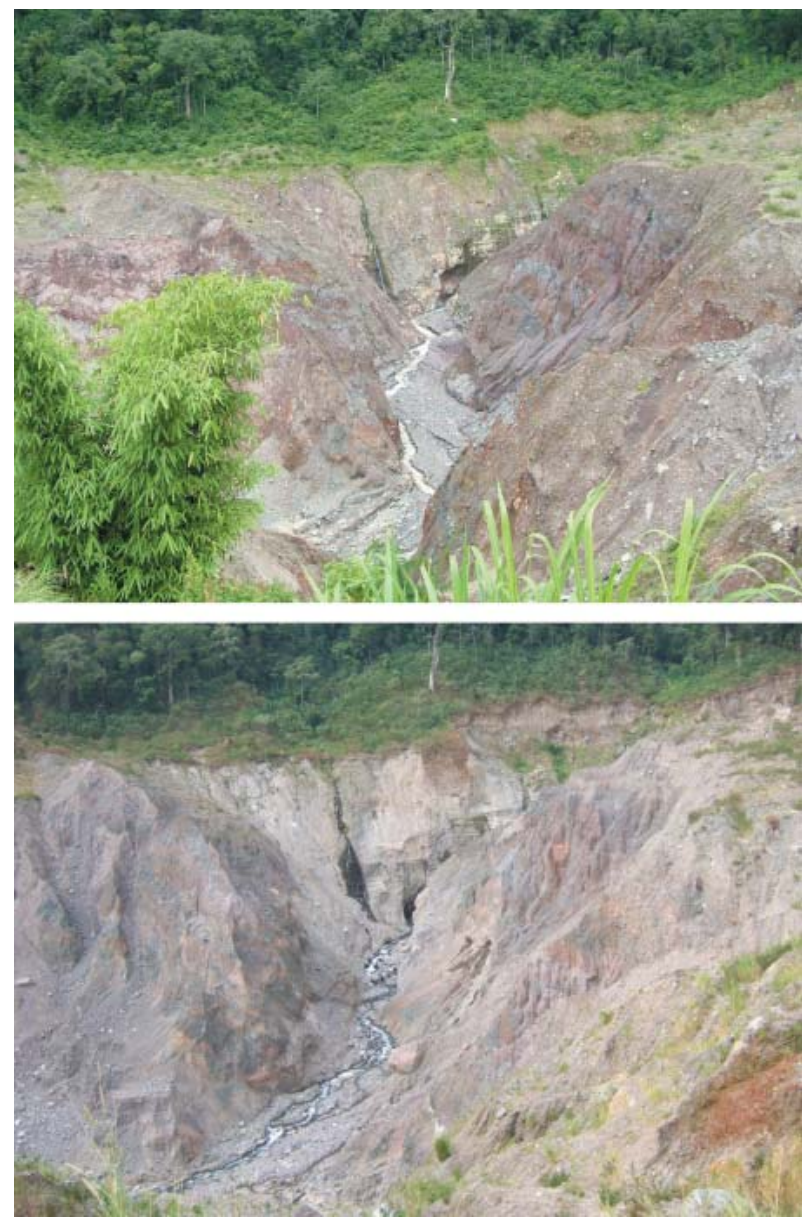

写真－ 5 B付近のガリー侵食状況（上：2005,下2006） Photo 5 Gully erosion near the point "B"

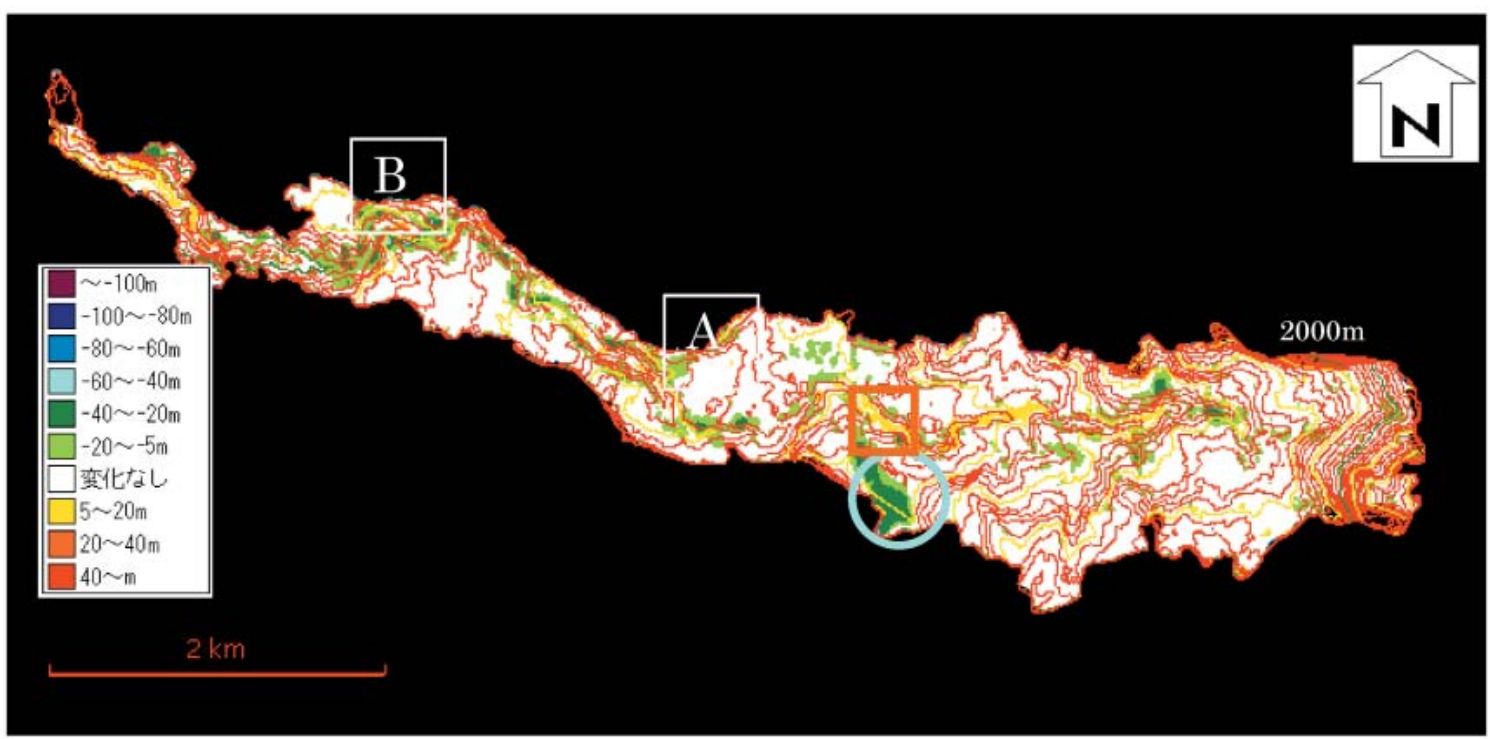

図－9 DEMの差分処理結果 (2005-06)

※一方向の変化 : $11,360,000 \mathrm{~m}^{3}$ 十方向の変化 $3,023,000 \mathrm{~m}^{3}$

Fig. 9 The result of the differentiation of the multi-temporal DEMs in 2006 and 2005.

Total degradations : $11,360,000 \mathrm{~m}^{3}$, Total aggradations $: 3,023,000 \mathrm{~m}^{3}$ 
で約60mに達する。

写真 -4 にカルデラ出口付近（写真 - 1 のA付近）の 崩壊発生から 1 年経過した状況を示す。写真 -2 と比較 して分かるとおり，崩壊発生時には堆積土砂により元の 河床を埋塞した平坦面が形成されていた状況から新たに ガリー侵食が進んでいることが確認できる。

また，写真 - 1 のB付近のガリー侵食状況を写真 -5 に 示す。 崩壊発生年（2004）のDEMと崩壊発生 1 年後 （2005）のDEMの差分処理で計算された，標高が低下し た範囲の体積（侵食により流出した土砂量に相当する） は約 37.5 百万 $\mathrm{m}^{3}$ その面積は約 2.2 百万 $\mathrm{m}^{2}$ であり，標高が 上昇した範囲の体積（侵食されて流下した土砂が流下途 中で堆積した量）は約 1.2 百万 $\mathrm{m}^{3}$ 面積は約 17 万 $\mathrm{m}^{2} て ゙ （$ 表 $-2)$ ，その差の約 36.3 百万 $\mathrm{m}^{3}$ が下流に流下したものと 考えられる。(表-2）これは山体崩壊によって発生し た崩壊土砂量約 2 億 $\mathrm{m}^{3}$ の約 $20 \%$ に相当する。

土砂量の算出にあたっては，誤差を見込んで変化なしの 範囲 \pm 5 mを除外して算出している。

\section{3 山体崩壊の発生 2 年後について}

図 -9 にさらに 1 年後の 2005 年とその 1 年後の 2006 年 のDEMにより算出された標高の差を計算した結果を示 す。

山体崩壊の発生 1 年後と同様の理由から $\pm 5 \mathrm{~m}$ は変化が ないものと考える。図－ 9 には差の計算結果に 2005 年の DEMより生成した $20 \mathrm{~m}$ 等高線を図 -7 同様に重ね合わ せた。DEMの差分処理より標高が低下した範囲の堆積 （侵食により流出した土砂量に相当する）は約 11.4 百万 $\mathrm{m}^{3}$ その面積は約 95 万 $\mathrm{m}^{2}$ であり，標高が上昇した範囲の 堆積 (侵食されて流下した土砂が流下途中で堆積した量) は約 3.0 百万 $\mathrm{m}^{3}$ 面積は 33 万 $\mathrm{m}^{2}$ で (表 -2 )，その差の約 8. 3百万 $\mathrm{m}^{3}$ が下流に流下したものと考えられる。 土砂量の算出にあたっては，誤差を見込んで変化なしの 範囲 \pm 5 mを除外して算出している。

図-8のような急激な低下域が見られなくなるととも

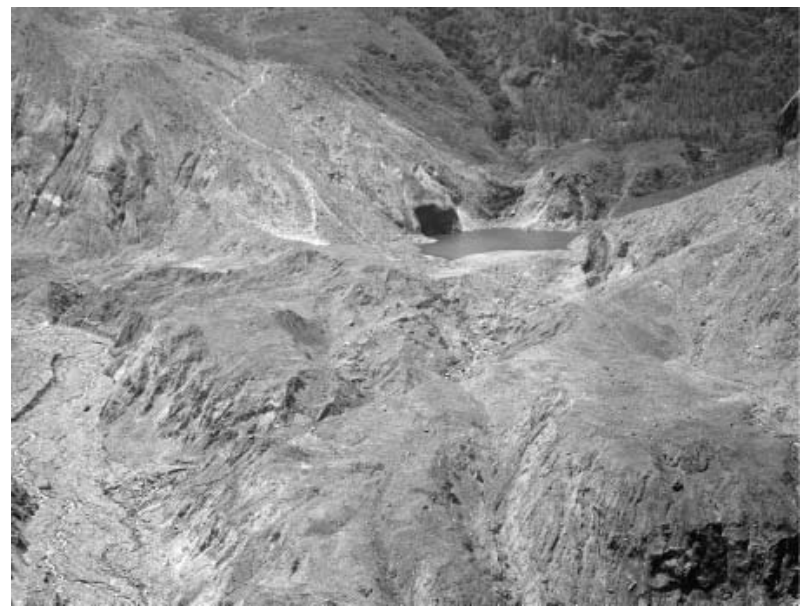

写真一 6 天然湖下流の侵食状況

Photo 6 Gully erosion in the lower reach of a natural lake
に，低下域の幅が狭くなったほか，一部の区間では堆積 域が現れる（例えば図－9の四角の範囲）などガリーの 発達状況に変化が見られた。また，左岸側に図－9の円 で囲まれた範囲で顕著な低下域が見られる。この地点に は2005年の衛星画像では天然湖の形成が確認されている。 DEM作成においては，水面では画像がマッチングしな いため近傍湖岸の標高を内扱している。この変化領域は 天然湖の決壊に伴う水面の低下と天然湖岸の決壊 - 侵食 による低下域を示していると考えられる。写真－6に天 然湖壁面の侵食状況を示す。このガリー侵食により流出 した土砂がジェネベラン川に堆積し，これより上流から のガリー侵食土砂がジェネベラン川に沿って堆積した結 果，上記堆積域が現れたものと考えられる。

\section{4 横断面の変化}

期間内の堆積土砂の変化をより詳細に把握するために 図－10に示す 12 断面をとり，作成した横断図を図 - 11 に 示す。

全般的に 2004 年から 2005 年の約 1 年間で縦横方向にガ リー侵食が進んだ後2005年から 2006 年の約 1 年間では大 きな変化はなく，侵食についてはおおむね停止したもの の，いくつかの断面では上記で述べたのと異なる変化を 示した。それらの地点について以下詳細に述べる。

No.1では2005年から2006年の間にガリーを埋めるよ うな変化が見られた。写真 -7 にNo. 1 付近のSPOTの才 ルソ画像を示す。ガリー側壁の押し出しのもととなる上 部の斜面変状については確認ができなかったものの，ガ リー底の形状が2005年に比べて2006年が滑らかになって おり，横断図に見られるガリーを埋める変化を裏付ける ものとなっている。

No. 5は2004年から2005年だけでなく，2006年になっ ても侵食が止まっていない。図 - 7〜9のBにあたると ころである。写真－5に示したとおりガリー侵食が進ん でいる。この地点においては2005年と2006年に行った現 地調査により計測を実施しており，約 $12 \mathrm{~m}$ の侵食による 河床の低下を観測している。横断面図の示す変化はこの 結果ときわめて整合した結果を示している。

No.8は近傍の断面でほとんど変化が無かったのに比 較して河床が上昇した断面である。写真 -7 に断面No. 8

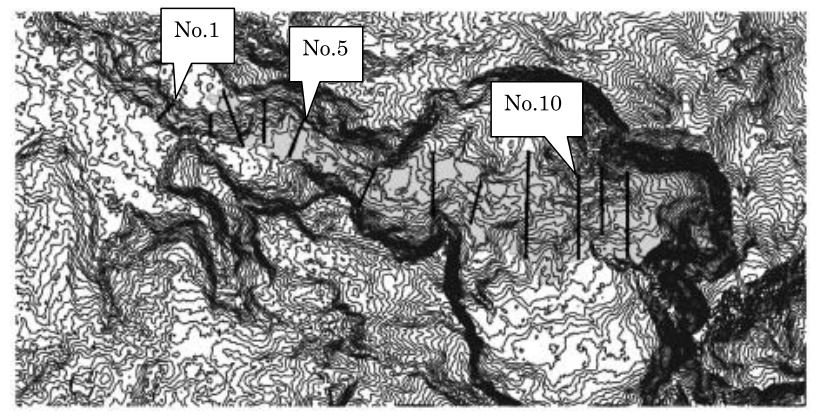

図-10 横断面位置図

（図左側下流から上流に向かってNo. 1〜 12）

Fig. 10 Location of Cross-sections 

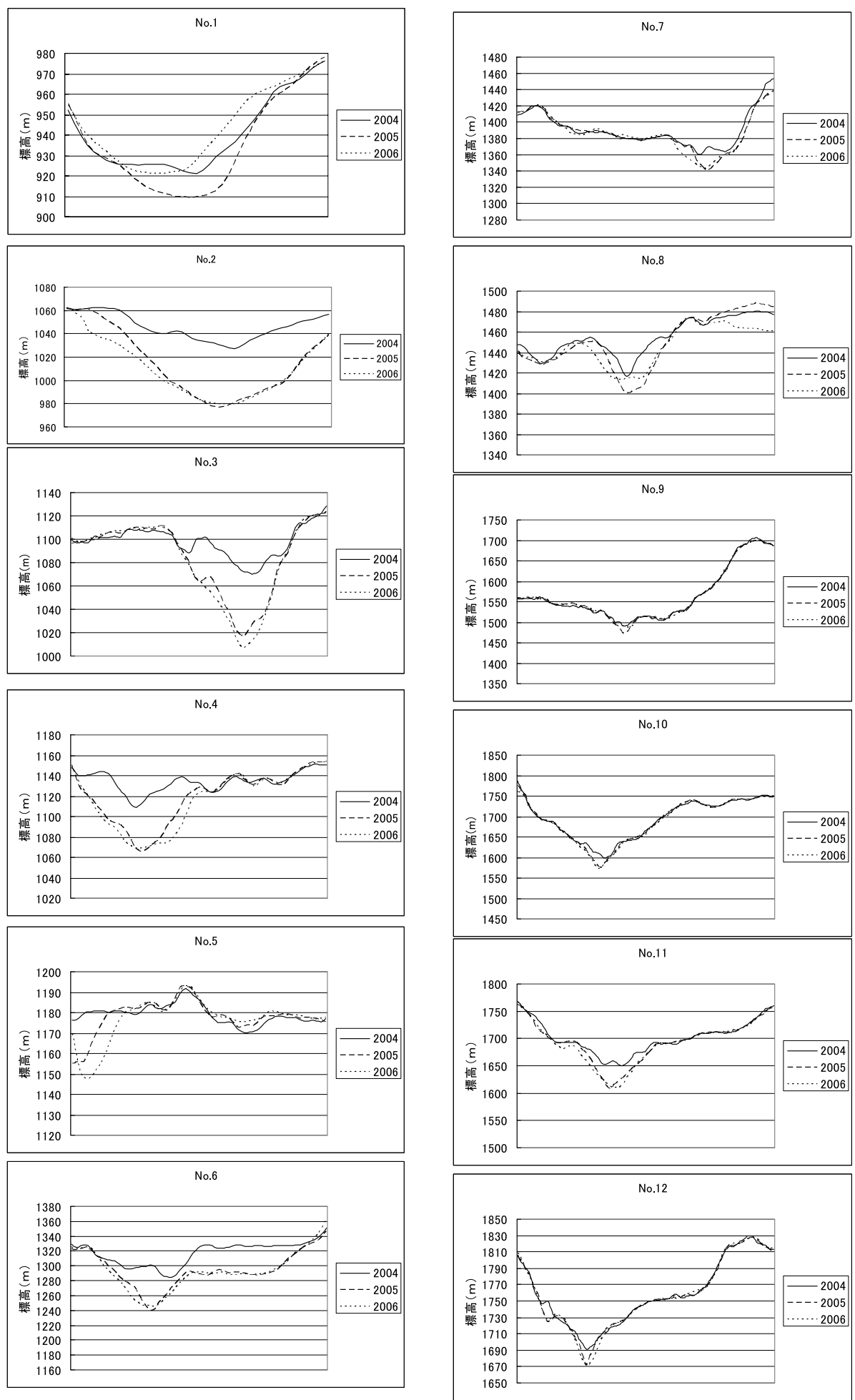

図-11＼cjkstart横断面図（下流から上流の向きに見て作成）

Fig. 11 Cross sections (The left side of the figures corresponds to the right bank)

付近のSPOTオルソ画像を示す。

2005年と 2006年の間に天然湖の堤体が決壊しその土砂が ジェネベラン川に流出しガリーを埋塞するとともに上流 からの土砂を堆積させ，その結果ガリーの谷底を上昇さ せたことが示されている。

\section{5. 考察}

本研究は大規模な崩壊による大量の不安定土砂が生産 された後，短期間に変化する侵食過程を衛星画像より作 成したDEMの差分解析により明らかにしたものである。

図-12に変化量のグラフを示す。一方向のグラフが崩 壊もしくは侵食量を，＋方向のグラフが堆積土砂量を， 差が流域外への流出土砂量を示す。 

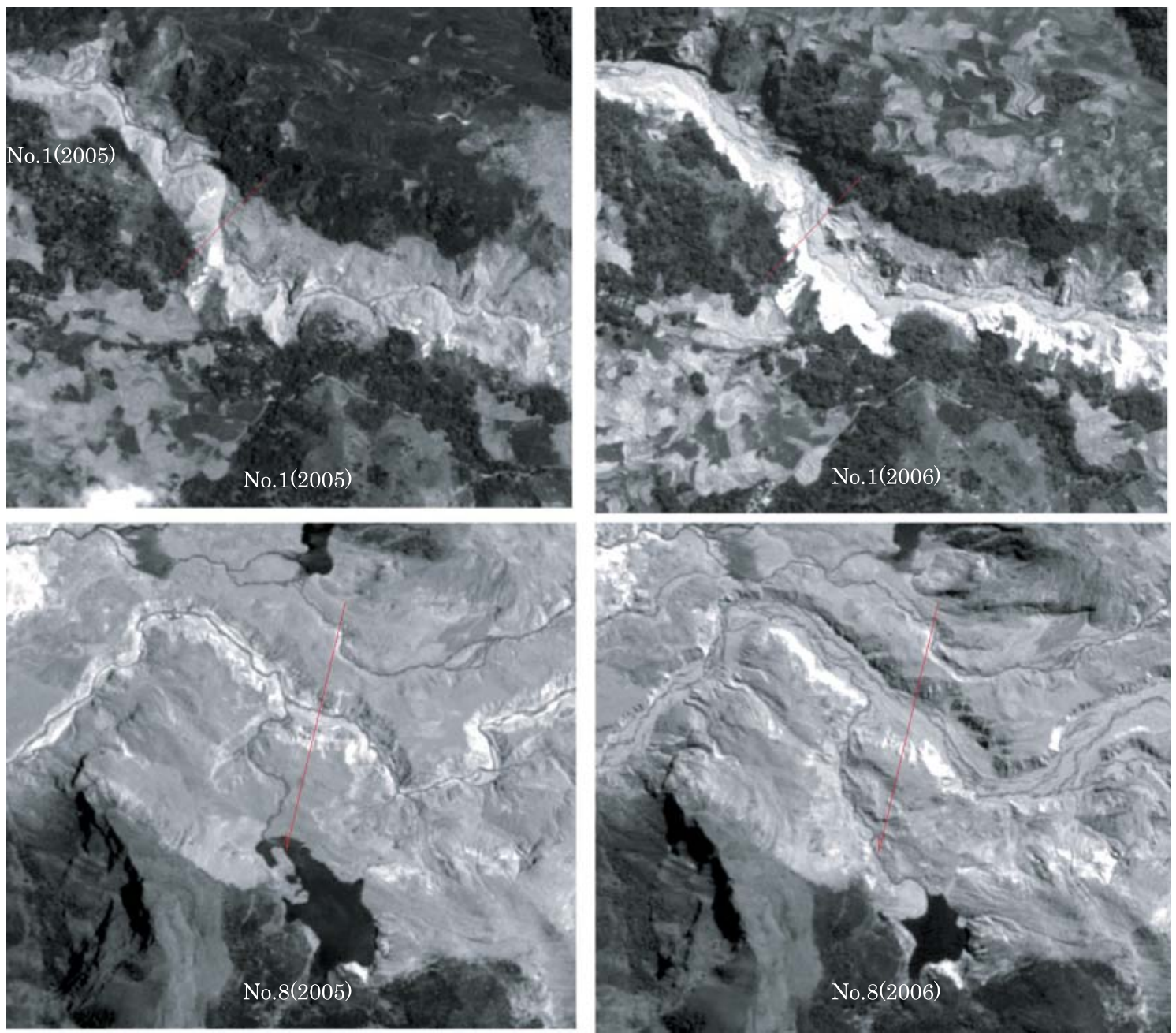

写真ー 7 No.1とNo8. 付近のSPOTオルソ画像（2005と2006）

Photo 7 SPOT ortho photos around the cross section No. 1 and No. 8 in 2005 and 2006.

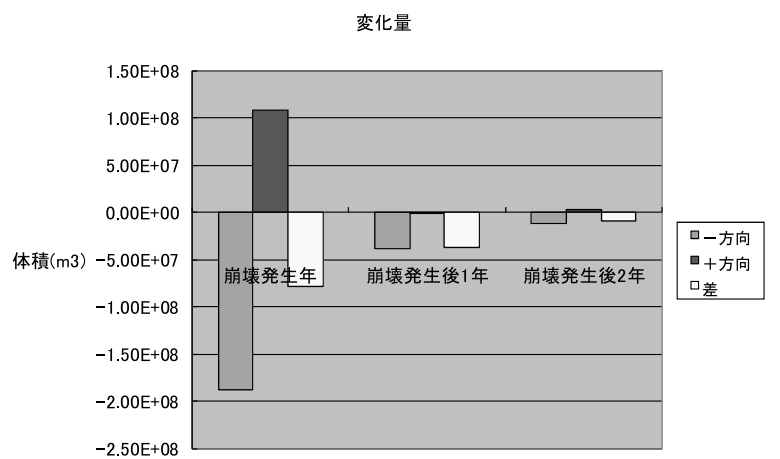

図一12 DEM差分処理による変化量

Fig. 12 The temporal change in the total aggradations, the total degradations and the residuals obtained from the differentiations of the multi-temporal DEMs

堆積土砂域の侵食量は調査した 2 年間で約 3 割弱に低 下した。その一方で堆積量は約 3 倍となり, 域外に流出 した量は 1 年目の約 36.3 百万 $\mathrm{m}^{3}$ から約 8.3 百万 $\mathrm{m}^{3}$ に低下 した。
本事例では，大規模な崩壊が発生した後 1 年において は，流水の影響を受けている部分では侵食による土砂の 流出が卓越し，厚く堆積した不安定土砂は，一方的に低 下する状態であったと考えられる。この傾向は, 2 年目に おいては一部区間において侵食と堆積がほぼ等しくなり, 侵食の傾向が収まる一方，一部区間ではむしろ堆積の傾 向を示す区間が現れこのため域外への流出土砂量が著し く低下する結果となったものと考えられる。

崩壊時から崩壊 2 年後までの衛星観測高精度DEMの 解析と現地調查から大規模崩壊により生産された不安定 土砂の侵食・堆積の時間変化について以下のことが分 かった。

崩壊時に崩壊部分の標高が大きく下がり，下流の河谷 が埋塞しほぼ平坦な面を形成した。

崩壊発生から 1 年後の間にガリーを形成し，そのガ リーに沿って侵食傾向が著しかった。特にカルデラ出口 (A) とレンケセ集落直下流(B)のガリー屈曲部では侵食によ る谷壁の後退と，谷底面の下刻が著しかった。

崩壊発生から 2 年後の間に，レンケセ集落直下流(B)に おいては依然としてDEMの差分処理で $46 \mathrm{~m}$ ときな侵 
食傾向を示すものの，それ以外の部分ではガリー沿いの 侵食傾向は弱まり，逆に天然湖上流など堆積傾向を示す 部分が現れるようになった。

\section{6. おわりに}

大規模な崩壊により発生した不安定な土砂の移動状況 は，発生後の経過期間によって変化することが既往の研 究によっても知られている。しかしながら，具体的にど のような経過をたどるか明確にされた事例は少ない，今 回の衛星画像を用いた解析により経年的かつ面的な変化 過程を把握することができた。

今後も本研究を継続してバワカラエン山の山体崩壊と その後の地形変化を衛星画像から作成したDEMを使っ て追跡することにより，さらにその実態を明らかにして いきたいと考えている。また，現地調查の結果と合わせ て堆積土砂の侵食過程について解析を進めて行きたいと 考えている。

\section{謝辞}

本研究に当たり, 現地観測デー夕の提供をしてくださ るなど多大なご協力をくださった（侏建設技術研究所イ ンターナショナル清水比呂志氏，八千代エンジニアリン グ侏渡辺岳志氏に感謝申し上げます。

\section{参考文献}

1 ）土屋智 - 古賀省三 - 笹原克夫 - 松井宗廣 $\cdot$ 中広三男 - 渡部文 人・沜大尚・吉田和久 (2004)：インドネシア南スラウェシ州 で発生した巨大崩壊と崩壊土砂の流出堆積 (速報), 砂防学会 誌, Vol. 57, No.3, p. $40-46$.

2 ) J. J. Major, T. C. Pierson, R. L. Dinehart, and J. E. Costa (2000) : Sediment yield following severe volcanic disturbance-A two-decade perspective from Mount St. Helens, Geology, Vol. 28, No. 9, pp. 819-822

3 ) A. S. Daag, Ph. D thesis: Modelling the erosion of pyroclastic flow dposits and the occurrences of lahars at Mt. Pinatubo, Philippines, Univ. of Utrecht, Netherland, p. 238

$4 ）$ 金子正則・笹原克夫・竹内正信・南 哲行・スバルカ （2001）：1998年 7 月にインドネシア・メラピ火山で発生した 火砕流堆積物の侵食状況, 砂防学会誌, Vol. 54, No. 1, pp. 59 $-65$

5 ）小橋澄治・水山高久（1996）：流出土砂量の予測, 雲仙火山砂 防研究報告, 第 2 号, 社砂防学会, pp. $19-26$

6 ) Government of The Republic of the Indonesia, Ministry of Public Works The Directorate General of Water Resources (2006) : Report on urgent survey for Consulting Engineering Services Bawakaraeng Urgent Sediment Control Project

7 ) H. Fujisada, G. B. Bailey, G. G. Kelly, S. Hara, and M. J. Abrams (2005) : ASTER DEM Performance, IEEE TRANSACTIONS ON GEOSCIENCE AND REMOTE SENSING, VOL. 43 , NO. 12 , pp. $2707-2714$.

8 ) K. Tsutsui, S. Rokugawa, H. Nakagawa, S. Miyazaki, C. -T. Cheng, T. Shiraishi, and S. -D. Yang (2007): Detection and Volume Estimation of Large-Scale Landslides Based on Elevation-Change Analysis Using DEMs Extracted From High-Resolution Satellite Stereo Imagery, IEEE TRANSACTIONS ON GEOSCIENCE AND REMOTE SENSING, VOL. 45, NO. 6, pp. $1681-1696$.

9 ）八千代エンジニアリング株渡辺岳志氏私信 （原稿受付2007年12月 3 日，原稿受理2008年 6 月 4 日） 